\title{
Satellite-based observation of lightning climatology over Nepal
}

\author{
Kumarjit Saha $^{1}$, Narayan Prasad Damase ${ }^{1,2}$, Trisanu Banik ${ }^{1,3}$, \\ Bapan Paul ${ }^{1}$, Shriram Sharma ${ }^{2}$, Barin Kumar De ${ }^{1}$ and Anirban Guha ${ }^{1, *}$ \\ ${ }^{1}$ Department of Physics, Tripura University, Suryamaninagar, Tripura, India. \\ ${ }^{2}$ Department of Physics, Amrit Science College, Tribhuvan University, Kathmandu, Nepal. \\ ${ }^{3}$ North Eastern Space Applications Centre, Umiam, Meghalaya, India. \\ ${ }^{*}$ Corresponding author. e-mail: anirban1001@yahoo.com
}

MS received 16 May 2018; revised 4 March 2019; accepted 3 June 2019

The lightning climatology over Nepal is analysed in detail for the first time. For the analysis, we utilised the satellite-based lightning imaging sensor data for the period from 1998 to 2013. A comparison of these climatological results is also performed with two ground-based lightning detection networks, namely, the World Wide Lightning Location Network and the Global Lightning Network for 3 yr from 2011 to 2013. On analysing the data obtained from the three sources, we conclude that the months of April and May are extremely vulnerable in the perspective of lightning hazards in Nepal, in contrast to the results reported previously which indicated that the maximum lightning activity occurred in the month of June. The central and eastern regions of the country receive the majority of lightning strikes during the months of April and May. The present finding is supported by the thunderstorm frequency data obtained from the disaster Information Management System, Nepal and also from thunder-day data from NOAA.

Keywords. Lightning climatology over Nepal; lightning detection efficiency; hydrometeors.

\section{Introduction}

Lightning is a natural atmospheric phenomenon. Tropical continental regions like Africa, South America and the Maritime Continent are the most lightning-prone regions of the globe (Christian et al. 2003). On a regional scale, the characteristics of lightning are affected by local topography (Goswami et al. 2010) and various meteorological factors such as surface temperature (Williams 2005; Jayaratne and Kuleshov 2006; Khain 2009), relative humidity (RH) (IPCC 2007), wind shear (Lee et al. 2008, 2010; Fan et al. 2009), ozone and other trace gas distribution (Pawar et al. 2012) and aerosol loading (Wang et al. 2011). The Himalayan region is mainly influenced by the large amount of water Published online: 08 August 2019 vapour arriving from the Indian Ocean (Malla 2008). The orographic lifting of the moist air in the Himalayan region also plays a major role in the occurrence of lightning activity. The lightning flash activity is maximal in the arc-shaped area along the Himalayan foothills in the pre-monsoon season, gradually weakened and shifted to the north-west corner of Pakistan (Kumar and Kamra 2012). They also showed that lightning activity is closely related to the atmospheric convective activity and the surface temperature, but poorly correlated with the convective available potential energy (CAPE). In a certain latitude $\left(20-35^{\circ} \mathrm{N}\right)$, the formative time of convective cloud clusters (CCCs) and disorganised short-lived convection (DSC) vary in different parts of the Himalayas (Kumar and Kamra 2012). 
In the Gangetic plains, CCCs and DSCs begin in the evening, but at the Tibetan Plateau, it starts mainly around the mid-afternoon, but both are most active during midnight and in the early morning. So, this region acts as a major contributor to the regional lightning activity (Kumar and Kamra 2012) over the Indian sub-continent. Thus, a proper knowledge of the climatological features of lightning activity in the countries located within the Himalayan region deserves special attention.

For the present work, the total geographical area of Nepal is divided into five regions, the far western $\left(28.39-30.25^{\circ} \mathrm{N} ; \quad 80.07-81.81^{\circ} \mathrm{E}\right), \quad$ mid-western $\left(27.68-30.45^{\circ} \mathrm{N} ; 80.98-83.68^{\circ} \mathrm{E}\right)$, western $(27.33-$ $\left.29.33^{\circ} \mathrm{N} ; \quad 82.70-85.20^{\circ} \mathrm{E}\right)$, central western $\left(26.57-28.39^{\circ} \mathrm{N} ; 83.92-86.57^{\circ} \mathrm{E}\right)$ and the eastern region $\left(26.35-28.11^{\circ} \mathrm{N} ; 86.13-88.20^{\circ} \mathrm{E}\right)$. Different regions are shown in figure 1 . The boundaries of the country lie between latitudes $26-30^{\circ} \mathrm{N}$ and longitudes $80-88^{\circ} \mathrm{E}$. Mountains, hills and plains are the three physiographic areas in Nepal. The northern part of Nepal is the mountainous region bounded by the Himalayas. The mean sea level (MSL) altitude of Nepal rapidly increases from the south to the north direction from about 70 to $8848 \mathrm{~m}$ MSL. The climate also changes according to the MSL altitude. The lower part of Nepal is mainly humid and warm, while the mountainous part is much colder and less humid (Robinson and Henderson-Sellers 1999).

Several research groups have studied the summer monsoon characteristics and its effects over the Himalayan region (Barros et al. 2000; Krishnamurti and Kishtawal 2000; Shrestha 2000; Lang and Barros 2002; Barros and Lang 2003). Some of the research groups investigated the temperature, wind, precipitation and outgoing long wave radiation flux from the Tibetan plateau in the summer monsoon for 80 days (He et al. 1987). The ratio of cloud-to-cloud lightning and cloud-toground lightning were studied over the Kathmandu region, Nepal (Baral and Mackerras 1992). They studied the lightning data from March 1987 to November 1988 using the CGR3 counted lightning database. It was found that almost no lightning occurred during the winter seasons and the activity mainly rose up from the month of February and continued up to the month of May. From the month of June, the activity gradually decreased during the observational period. Similar results were found by Kayastha and Regmi (2008). In general, the thunderstorm activity also peaks during the pre-monsoon seasons. It is found that the atmospheric water vapour accumulated from

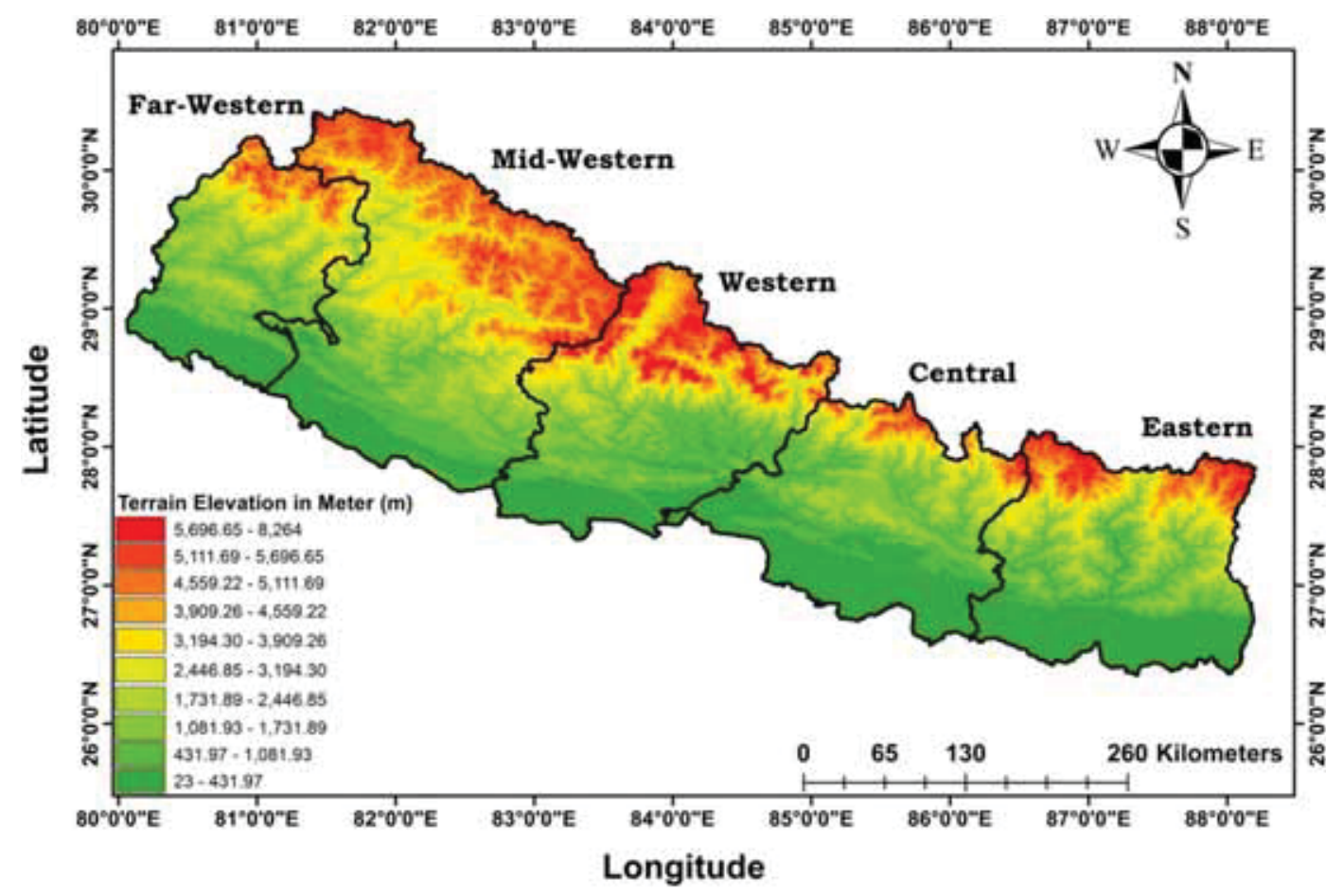

Figure 1. Nepal is topographically divided into three major regions. The upper region (red-coloured region in this figure) of Nepal has mountains (Himalayan region) with the highest mountain peak in the world. The yellow coloured region in the middle part of the country is covered by high hills and is stretched from the east to the west. The only plain region of Nepal lies close to the Indian border and is called the Terai region (green-coloured region in this figure). 
the Bay of Bengal region along with temperature instability orographic lifting which could mainly be responsible for generating thunderstorm activities over Nepal and also the north-eastern part of India during the pre-monsoon period (Sarkar et al. 1980; Srivastava et al. 2007; Kayastha and Regmi 2008).

Lightning is one of the natural phenomena that brings about loss of life and property in addition to flood, landslide, fire and earthquake. According to the National Emergency Operation Center of Nepal, in the year 2013, the number of deaths reported due to lightning was more than 140 . So, it is very important to investigate the spatio-temporal variability of the lightning-prone zones in the country with the help of climatological studies of lightning activity for effective planning and policy making for any kind of precautionary measures.

\section{Database for the present analysis}

Presently, a number of lightning detection methodologies exist. Some are satellite based and some are ground based. For the present analysis, we used lightning imaging sensor (LIS), World Wide Lightning Location Network (WWLLN) and Global Lightning Network (GLN) data over Nepal. The thunderstorm day data were collected from Desinventar, a free and open source disaster information management system maintained by the United Nations office for the Disaster Risk Reduction (UNISDR) (http://www.desinventar. net/DesInventar/profiletab.jsp). Scientifically significant reanalysis wind data, surface temperature data and RH data were collected from the National Center for Atmospheric Research (Kistler et al. 2001; Price and Asfur 2005) (https://www.esrl. noaa.gov/psd/data/gridded/data.ncep.reanalysis. surface.html). CAPE and convective inhibition reanalysis (CIN) data were collected from the physical division branch of the NOAA website. The NOAA data may be accessed from the link https:// www.esrl.noaa.gov/psd/data/gridded/data.narr. monolevel.html. For hydrometeors, we have collected radar reflectivity data from Cloudsat. The product 2B-GEOPROF (Mace et al. 2007) provides the reflectivity values (https://www. cloudsat.cira.colostate.edu/).

\subsection{Weather Services International (WSI) GLN}

GLN is a partnership of WSI and the time-of-arrival system, an integrated lightning location and detection system. For the advancement of lightning detection, more than 150 GLN sensors are strategically placed on international hosting partner sites. In Nepal, it is located at the Nepal Academy of Science and Technology (NAST). The network may detect both clouds to ground (CG) flashes and intra-cloud (IC) flashes with an efficiency of $95 \%$ and $10 \%$, respectively (https:// www.unidata.ucar.edu/blogs/news/entry/global_ lightning_data_now_available). The range of detection of the antenna is about $400 \mathrm{~km}$ (base line).

\subsection{World Wide Lightning Location Network}

WWLLN is a GLN of very low frequency receivers, operated by the University of Washington, USA, in collaboration with universities and government labs. An electric or magnetic field antenna, a GPS receiver and an internet-connected processing system are required to locate and detect the lightning position and time anywhere on the Earth using the time of group arrival technique (Dowden et al. 2002). In the year 2003, only 10 sensors were working globally and steadily increased to more than 70 sensors by 2013 (Hutchins et al. 2013; Rudlosky and Shea 2013). These group arrival times are transmitted to the central processing system for a time of arrival analysis to determine lightning locations in real time. The efficiency of the network increased day by day as the number of receivers increased, starting from $1.7 \%$ to $11 \%$ up to 2013 (Rudlosky and Shea 2013; Soula et al. 2016).

\subsection{Lightning imaging sensor}

LIS is a space-based lightning detection system onboard the Tropical Rainfall Measuring Mission satellite to detect lightning distribution and variability of total lightning (CG and IC). LIS detects the lightning occurrence along the orbital swath of the satellite with a temporal resolution of $2 \mathrm{~ms}$ and the spatial resolution of 4-7 km over a large region of the Earth's surface (Siingh et al. 2014) and also 90-s snapshots of all types of lightning are provided by the polar satellites within $(600 \times 600) \mathrm{km}$ field of view (Christian et al. 1999; Rudlosky and Shea 2013). The resolution and coverage of the Earth depend on the orbit and the altitude of the sensor. The detection methodology of the sensors is also well explained by previous researchers (Boccippio et al. 2002). The flash detection efficiency of LIS 
varies up to $90 \%$ during the different time of the day (Christian and Goodman 1987; Cecil et al. 2014). LIS determines the location of flashes by using the time of the occurrences of a lightning flash and $0.50 \times 0.50$ latitude-longitude grid-wise monthly resolution data are recorded in the Global Hydrology Resource Centre (GHRC). The LIS data may be accessed freely at the link https:// lightning.nsstc.nasa.gov/lis/overview_lis_ instrument.html.

\section{Observational results}

Analysis of three different lightning detection systems comes up with different results in different years within the boundary of Nepal. The results are shown in figure $2(\mathrm{a}-\mathrm{c})$. We observed that the LIS (satellite-based) detected mean lightning flash rate density gradually increased from the month of January, was at its peak during the month of May and gradually decreased up to the month of December for $16 \mathrm{yr}$, as shown in figure 2(a). We also observed that the flash rate density showing decreasing trends along with the increasing altitude and also it shifted towards the western side of the Nepal, after the month of May. It is observed that, in general, in the northern parts of Nepal, lightning occurrence is less compared to the southern parts.

As different lightning detection systems have different detection efficiencies and limitation of data, we performed analysis for only 3 -yr data for the two ground-based networks, namely, WWLLN and GLN. As shown in figure figure $2(\mathrm{~b}$ and $\mathrm{c})$, we observe that all three receivers detect maximum lightning activity in the month of May 2011 compared to April and June. It is noted that the satellitebased receiver LIS detected maximum lightning in the month of May for $16 \mathrm{yr}$ (1998-2013), whereas two ground-based receivers WWLLN and GLN showed significantly different results in 2012 and 2013. In the years 2012 and 2013, WWLLN detected maximum lightning in the month of April and June, respectively, but GLN detected lightning shows completely the opposite picture.

To explore more information about the thunderstorm and the associated lightning over different regions of Nepal, we plotted figure 3 that represents the monthly variation of thunderstorm occurrence frequency in five regions of the country for $16 \mathrm{yr}$. The general trend shows that from the far western to the eastern region, the thunderstorm activity gradually increases from the month of
April to June. We observed that the maximum thunderstorm occurrence zones fall under the central and eastern parts of Nepal, which is contradictory from the results shown in figure 2(a), where the maximum lightning occurrence is observed in the western part of Nepal. This could be due to the fact that the Desinventar website collected the data when human lives are affected by lightning. This data source is not an exhaustive one in data collection but it is a very important source to know how many thunderstorms affected human beings within a certain period. The population density of the central region is double when compared with the western region. This could be a probable reason for the contradiction in between the most thunderstorm- and lightning-associated zones represented in figures 2(a) and $3(\mathrm{a}$ and $\mathrm{b})$.

Figure 4(a) shows the monthly variation of thunderstorm occurrence frequency for the period 1998-2013 over Nepal. There is a clear trend in the monthly variation of the peak activity during the month of May, but thunderstorm days peak in the month of April which are shown in figure 4(b). The thunder-day data analysis from NOAA depicts the same picture. In the month of May, the thunderstorm occurrence day is less compared to the month of April but the thunderstorm occurrence number is the maximum in May. This could be due to the fact that each day may encounter a number of thunderstorms, leading to the difference in the peak activity in the number of thunderstorm days and its occurrences.

The local time variations of the lightning activity as detected from the two ground-based (WWLLN and GLN) different lightning detection networks are shown in figure $5(\mathrm{a}$ and $\mathrm{b})$. The maximum occurrence of lightning activity during the local afternoon and early evening showed common features globally, but during local midnight and morning, the lightning activity prevailing by the short-lived convection, complex orography of Nepal, nocturnal complex mesoscale convective activity and low-level monsoon southwesterlies in the south-facing slopes of the Himalayan region (Barros and Lang 2003; Barros et al. 2004). This observation is consistent with the previous observations (Boeck et al. 1999; Kumar and Kamra 2012; Pawar et al. 2015).

The monthly mean surface temperature over Nepal for 16 yr monotonically increased from the month of January to May and again decreased monotonically from May to December as shown in figure 6(a). This figure illustrates that the Earth's 
(a)
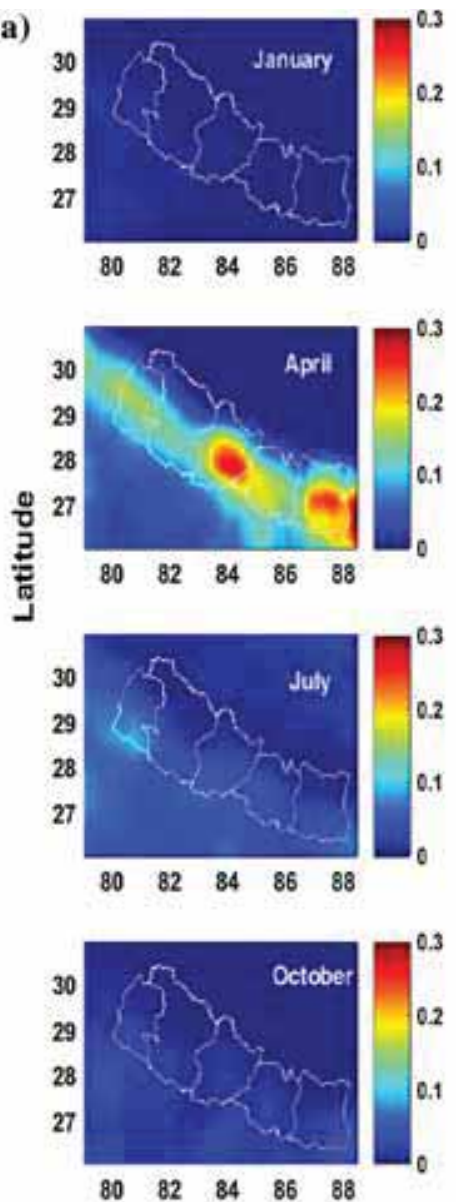
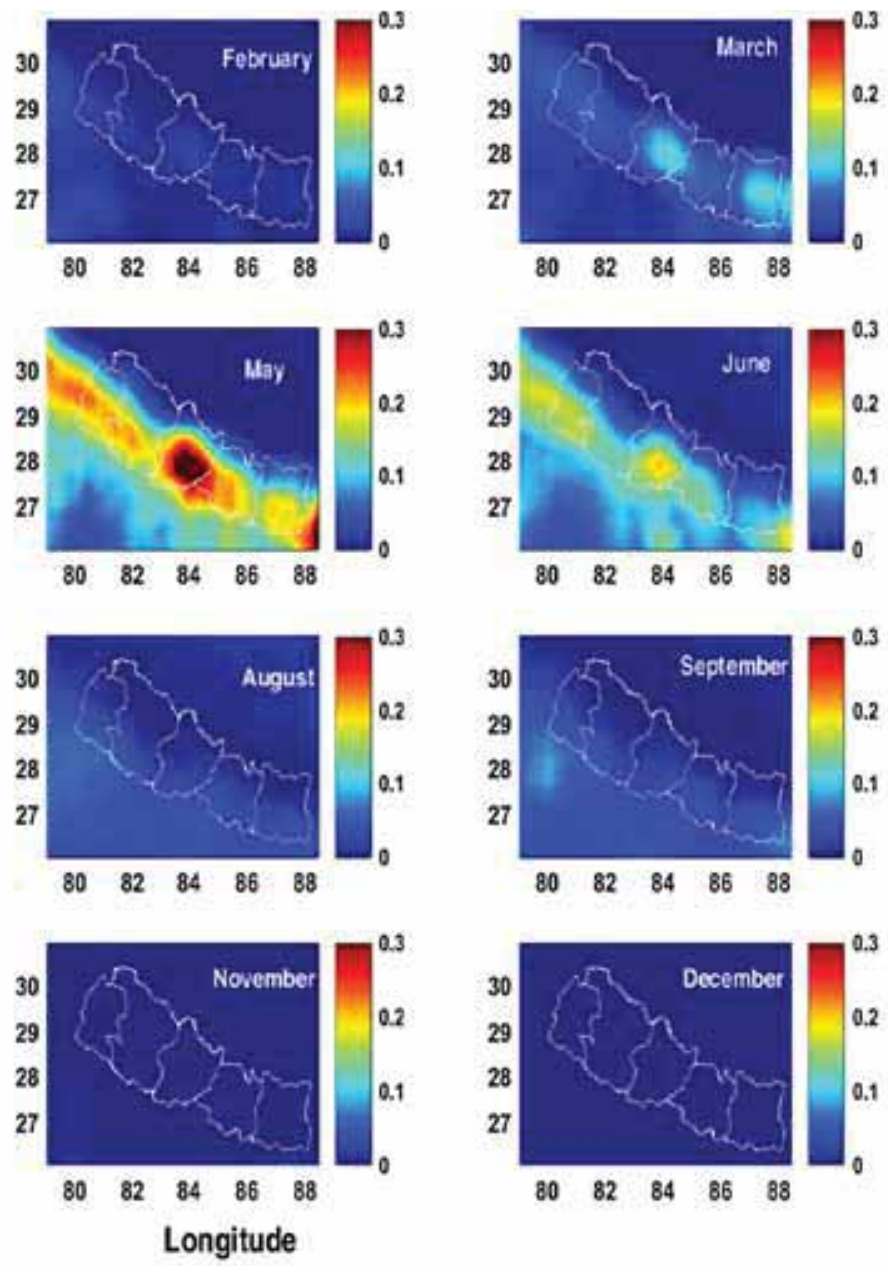
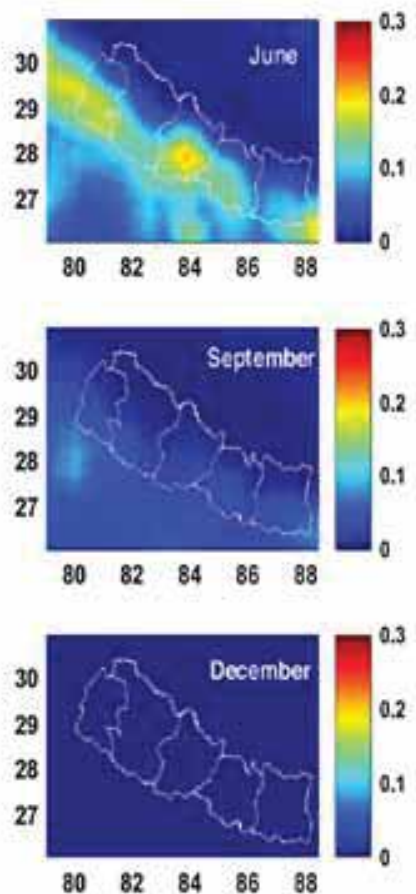

(b)

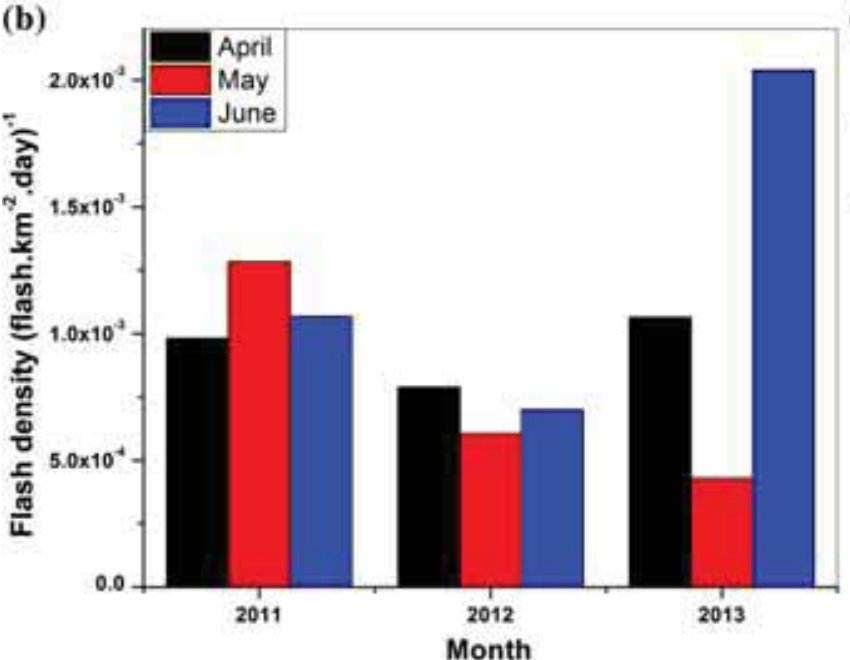

(c)

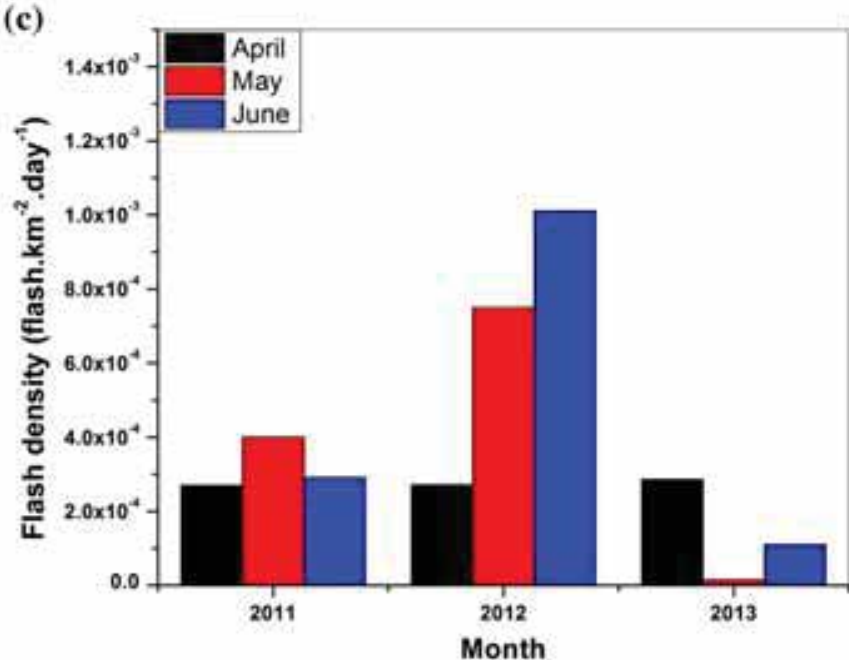

Figure 2. (a) Lightning flash rate density (flash $\mathrm{km}^{-2} \mathrm{day}^{-1}$ ) in the month of January to December over the whole of Nepal for the years 1998-2013. Data are collected by the LIS receiver. (b) The black, red and blue colour bars represent the monthly variation of the WWLLN receiver collected lightning flash density over Nepal during April, May and June for the years 2011, 2012 and 2013, respectively. (c) Monthly variation of lightning flash density over Nepal during April to June for the years 2011-2013. Data are collected from the GLN receiver.

surface warming up by more than $22^{\circ} \mathrm{C}$ in the month of May affects the vertical thermal profile of the atmosphere with a prevailing favourable condition to generate thunderstorms (Price and Asfur 2005). The mean surface temperature is the maximum in the month of May over the central 
(a)
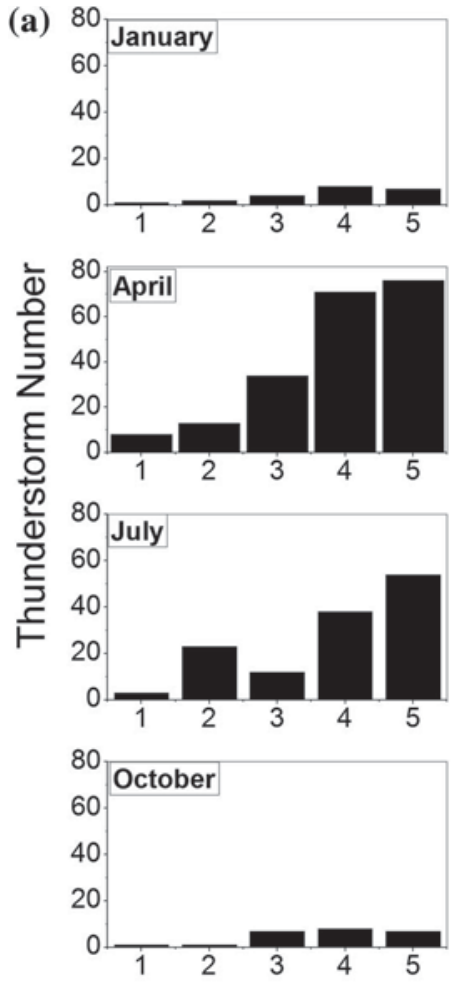

(b)
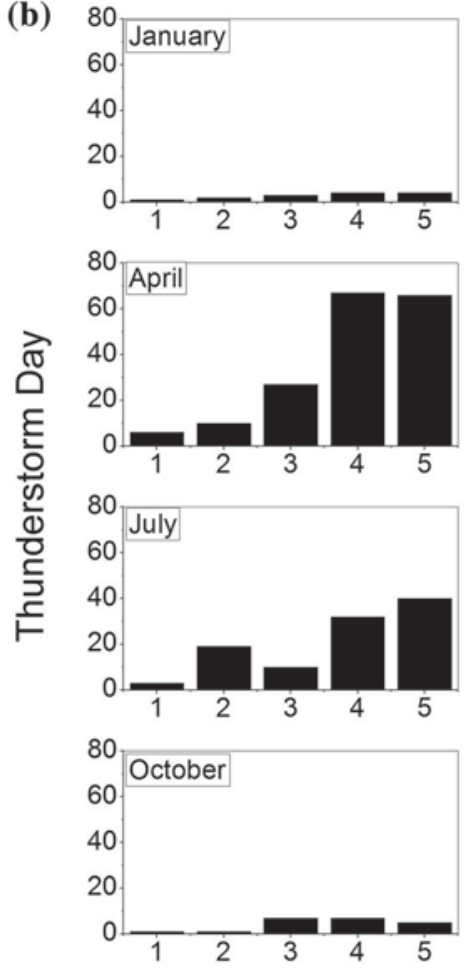
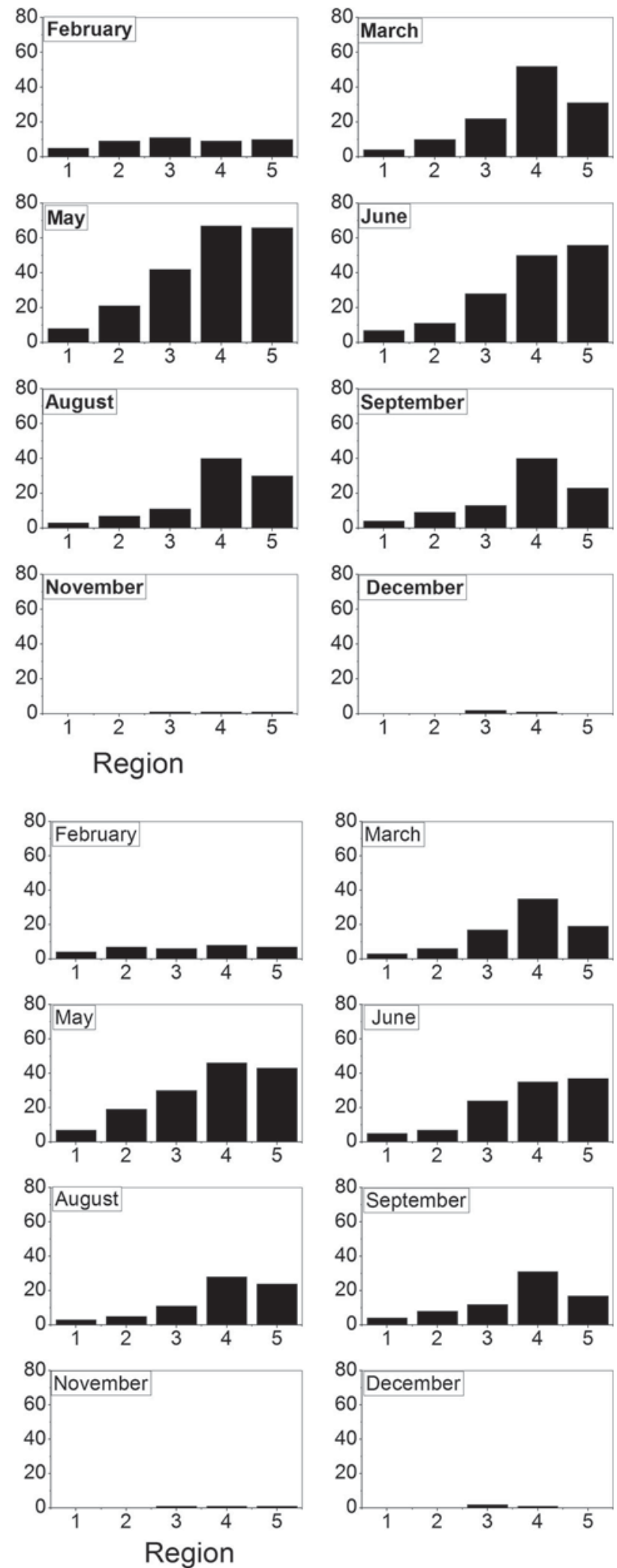

Figure 3. (a) The number of total thunderstorm occurrences in the five regions of Nepal for $16 \mathrm{yr}$ (1998-2013). The numbers along the $x$-axis represent the far western region, mid-western region, western region, central region and eastern region, respectively. The $y$-axis represents the total number of thunderstorms. (b) The number of total thunderstorm days in the five regions of Nepal for 1998-2013. The $x$-axis represents the April, May and June months, respectively. The $y$-axis represents the total number of thunderstorm days. 


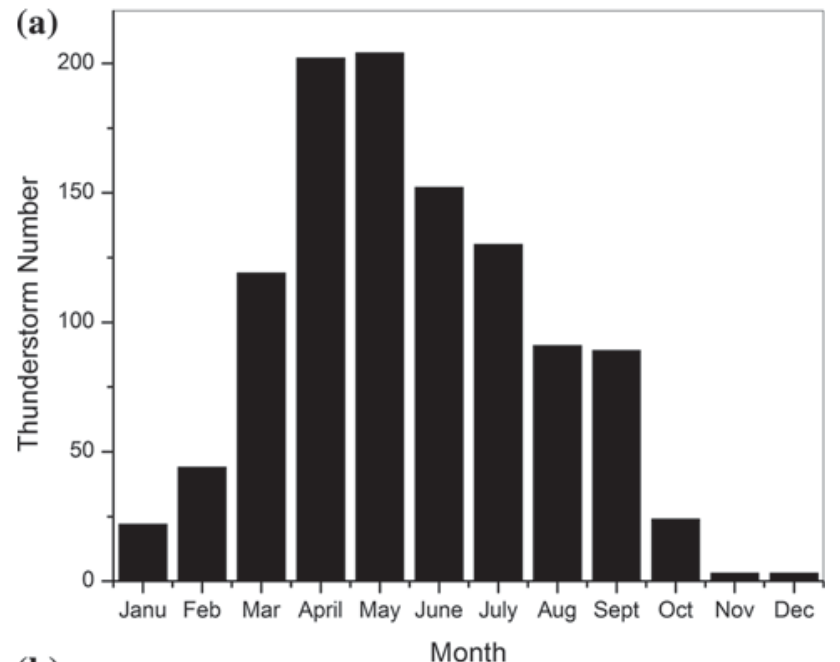

(b)

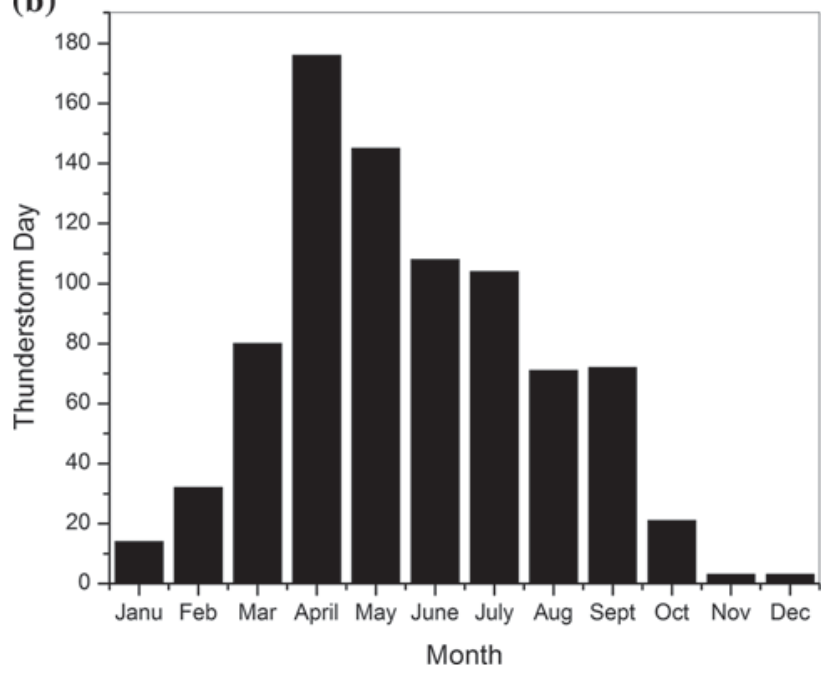

Figure 4. (a) Monthly variation of thunderstorm occurrence over Nepal during 16 yr from 1998 to 2013. (b) Monthly variation of thunderstorm occurrence days over Nepal during 16 yr from 1998 to 2013.

region which is shown in figure 6(b), this also supports the result of figure $3(\mathrm{a}$ and $\mathrm{b})$. The modified profile along with winds, $\mathrm{RH}$ and vertical stability determines the buoyancy and develops the clouds and enhancement in the lightning activity (Williams 2005; Jayaratne and Kuleshov 2006; Khain 2009; Kumar and Kamra 2012). As a result, maximum lightning occurs in the month of May and that could be due to the fact that the average surface temperature is the maximum in the central and eastern regions compared to the other regions.

Figure 7(a) represents the monthly mean variation of $\mathrm{RH}$ which points to the fact that the $\mathrm{RH}$ in the month of May crosses $50 \%$ which is favourable for the formation of a thunderstorm (Price and Asfur 2005). The pattern of RH over the different regions is similar to the whole Nepal region, i.e., the peak RH is associated with the monsoonal circulation which is shown in figure 7(b). It is comparatively high in the eastern region followed by western and central Nepal during the pre-monsoon season. From figure 8(a), we also observed that CAPE is not that much high in the month of May which is a general trend of the Himalayan foothills region and also the correlation between lightning and Cape is very less $(<0.2)$ (Kumar and Kamra 2012). The mean variations of CAPE over the different regions are shown in figure 8(b). This figure illustrates that the CAPE monotonically increases from the far western to the eastern region during the pre-monsoon season, which also supports the result of figure $8(\mathrm{a})$. The monthly variation of CIN over Nepal is observed in figure 9(a), which is the opposite in nature to that of CAPE. This figure illustrates that the CIN index is monotonically decreasing from January to July and again increasing thereafter. The major issue of CAPE and CIN measurement is the average over a whole day. Agnihotri and Dimri (2015) showed that during the pre-monsoon or thunderstorm-active periods, the CAPE/CIN during the whole day and night duration varies drastically. The main reason for such high variation could be due to the formation and dissipation of the storm during the same day of observation. During the month of April or May, we noticed that thunderstorms are more frequent. As a result, the averaging of CAPE/CIN over the whole day is highly affected by individual observation. For example, if one CAPE/CIN measurement is considered before the storm, then it will definitely show high value, but if CAPE is taken after the dissipation of the storm when the stability of the atmosphere is comparatively higher, then it will definitely indicate lower CAPE or high CIN values which drastically reduces the average of the CAPE over the whole day as well as the whole month. A similar trend is observed over different regions of Nepal, although the eastern region is the minimum during the pre-monsoon season which is shown in figure $9(\mathrm{~b})$.

In the months of April and May, moist maritime air from the south is separated by northern dry continental air near the coastal region of Bangladesh. But in the month of June, the same phenomenon does not occur despite the moist air impinging from the Bay of Bengal which is shown in figure 10 (Romatschke et al. 2010). As a result, strong specific humidity gradient near the Bangladesh region, short-lived convection and local orographic lifting leads to enhanced lightning activity in the north-eastern side of Nepal and also 

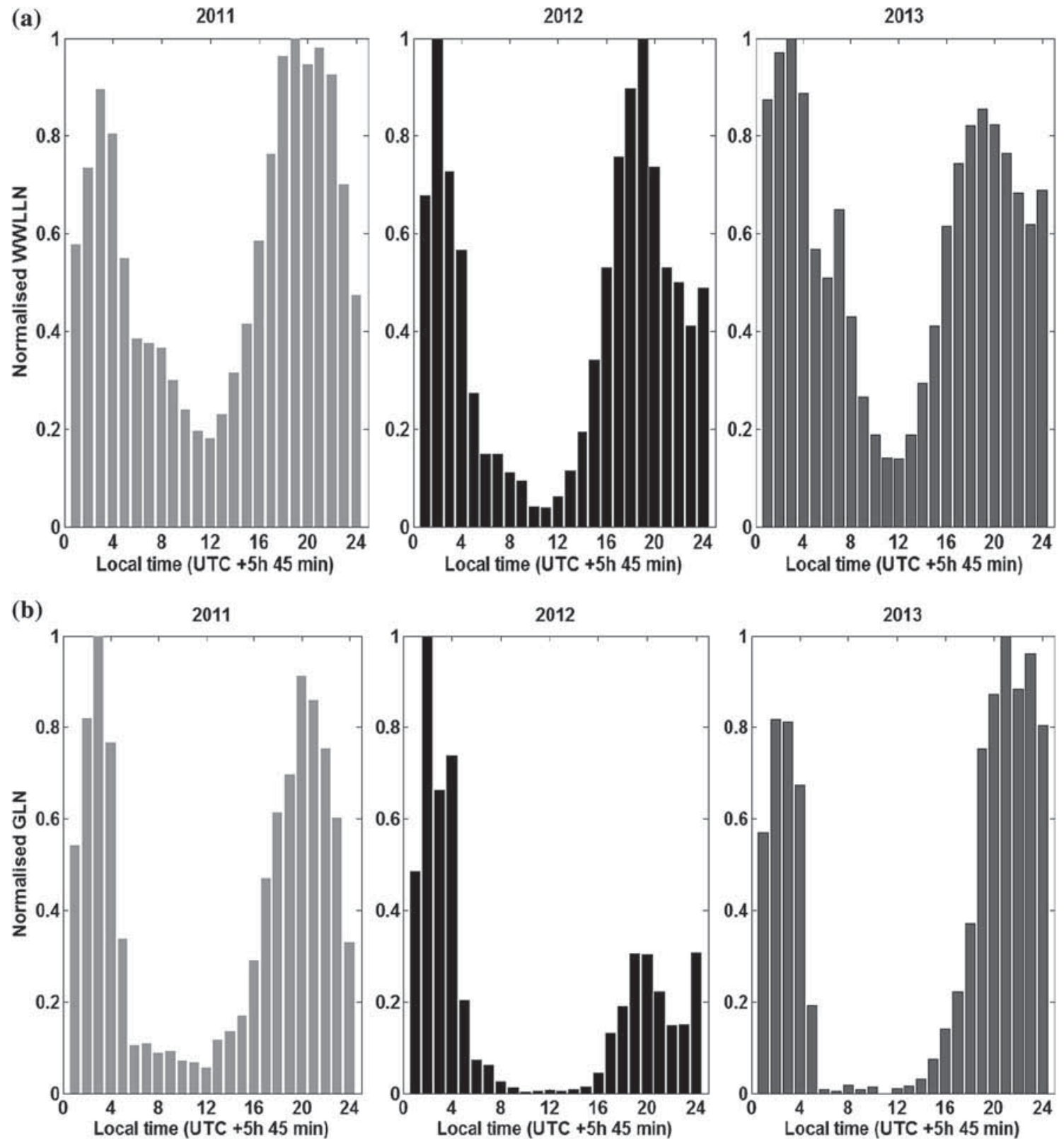

Figure 5. (a) The left (2011), middle (2012) and right (2013) panels represent the hourly normalised variation of the lightning flash count during the period of April to June over the whole of Nepal. The hourly lightning flash count data are divided by the highest flash count data for normalisation. Each bar represents the hourly WWLLN detected normalised lightning flash counts. (b) The left (2011), middle (2012) and right (2013) panels represent the hourly normalised variation of lightning flash count during the period of April to June over the whole of Nepal. The hourly lightning flash count data are divided by the highest flash count data for normalisation. Each bar represents the hourly GLN detected normalised lightning flash count.

north-east India in the pre-monsoon season (March-May) (Barros et al. 2004).

\subsection{Role of hydrometeors over lightning}

The liquid or frozen water particles abundant in the atmosphere are called hydrometeors. They are mainly divided into two types: one is precipitation particle and the other one is cloud particles. Cloud particles consist of different sizes of ice crystals, water droplets, graupel, hail, etc. In the presence of water droplets, graupel particles collide with tiny ice crystals along with the ice-ice collision process prevailing during the thunderstorm-charging process (Saunders 1993). This process mainly occurs between the temperatures $-10^{\circ}$ and $-20^{\circ} \mathrm{C}$ in the mixed-phase region. Radar reflectivity is one of the best proxies to estimate the amount of hydrometeor present in the mixed-phase region (Pessi and Businger 2009). Different types of hydrometeors 

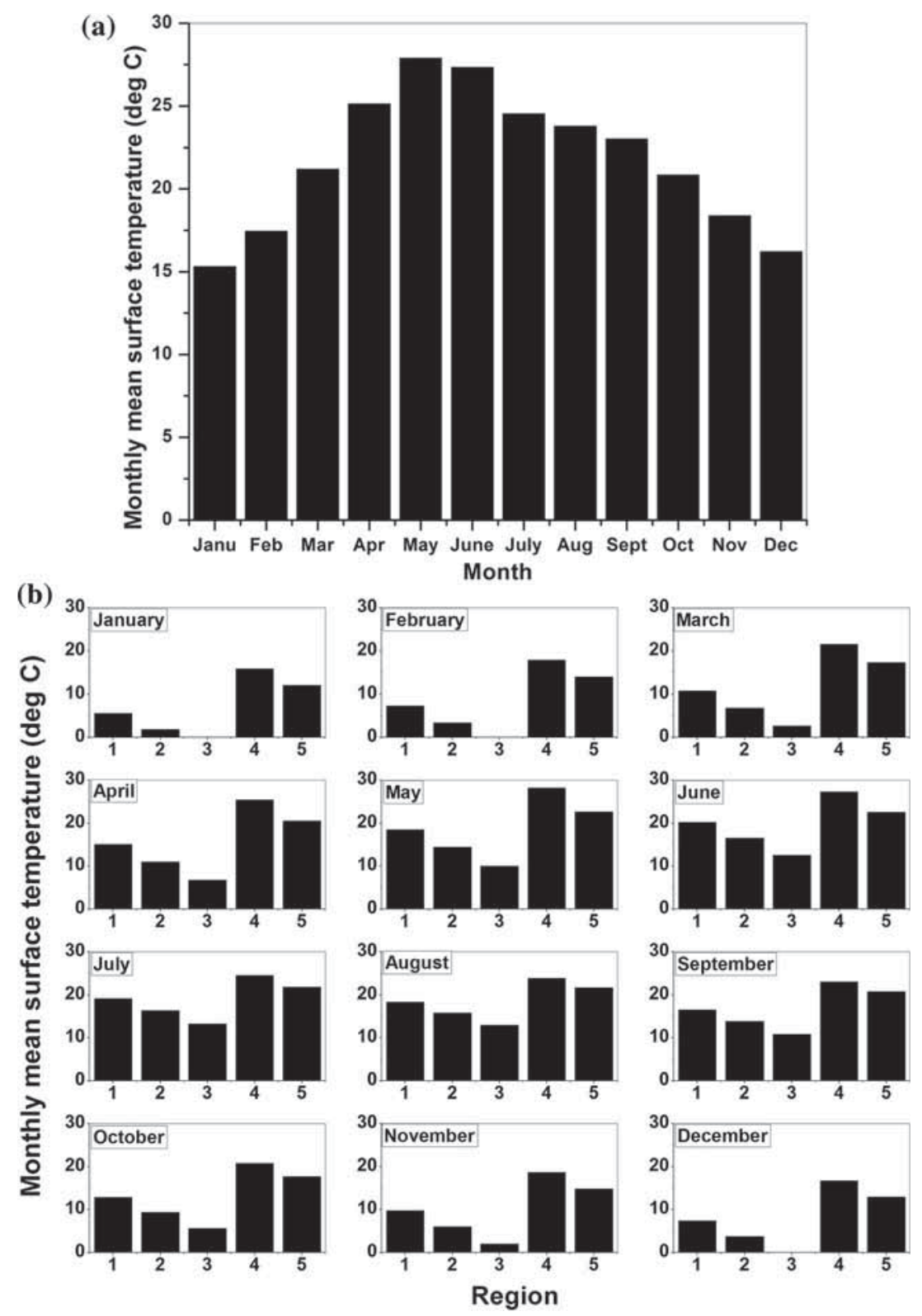

Figure 6. (a) Monthly mean variation of surface temperature over Nepal during 16 yr from 1998 to 2013. (b) Monthly mean variation of surface temperature over the five regions of Nepal during $16 \mathrm{yr}$ from 1998 to 2013.

present in the different heights of the cloud at different states, depending on the presence/absence of the supercooled water droplets and the rimming accretion rate of the graupel, the efficiency of the charging process increases/decreases (Mansell et al. 2005). Previous researchers have studied the charge distribution of the cloud by balloon and aircraft mission and found a $120 \mathrm{kV} / \mathrm{m}$ electric field at $5 \mathrm{~km}$ (Stolzenburg et al. 1998) and a $400 \mathrm{kV} / \mathrm{m}$ one at $6 \mathrm{~km}$ above the MSL (Winn et al. 1974). So, the electric field inside the cloud has exceeded the conventional breakdown threshold that helps trigger the lightning leader (MacGorman and Rust 1998; Rakov and Uman 2003).
Figure 11 illustrates that the radar reflectivity mainly comes from the Terai region of Nepal at an altitude of $10 \mathrm{~km}$ for $10 \mathrm{~s}$. The Terai region is much warmer than the hilly and the mountainous regions. As a result, atmospheric instability leads to an orographic lifting of the air parcels and may also enhance the aggregation and growth of the particles by coalescence that may lead to an increase in reflectivity. After that, the reflectivity decreases with height and that could be due to the fact that the hydrometeor size reduces and finally collapses to form a liquid drop (Das et al. 2017).

We attempted to study the climatological variation of hydrometeors associated with thunderstorms 
(a)

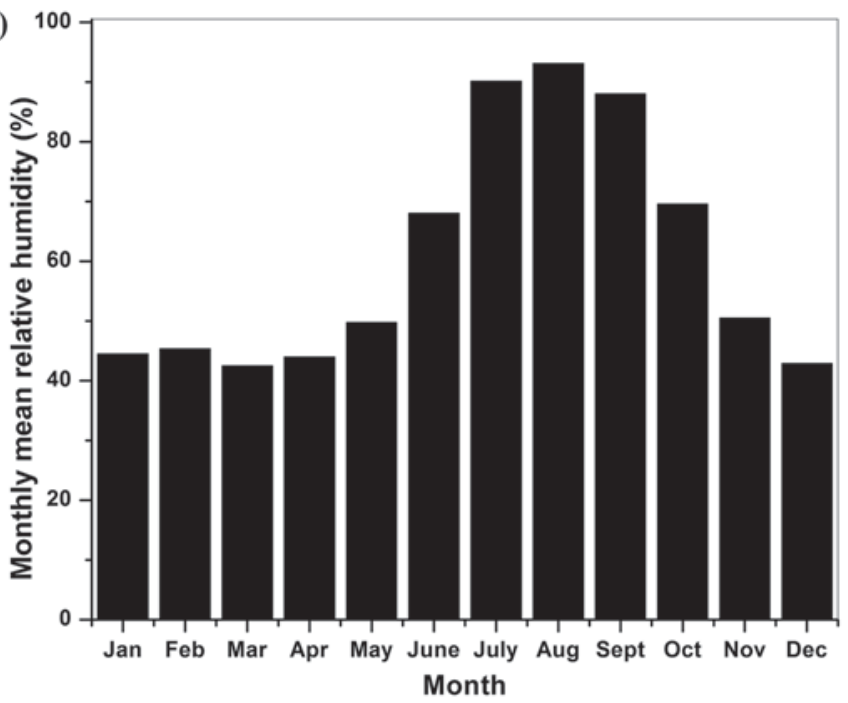

(b)

b) 120

20. January

\section{0.}
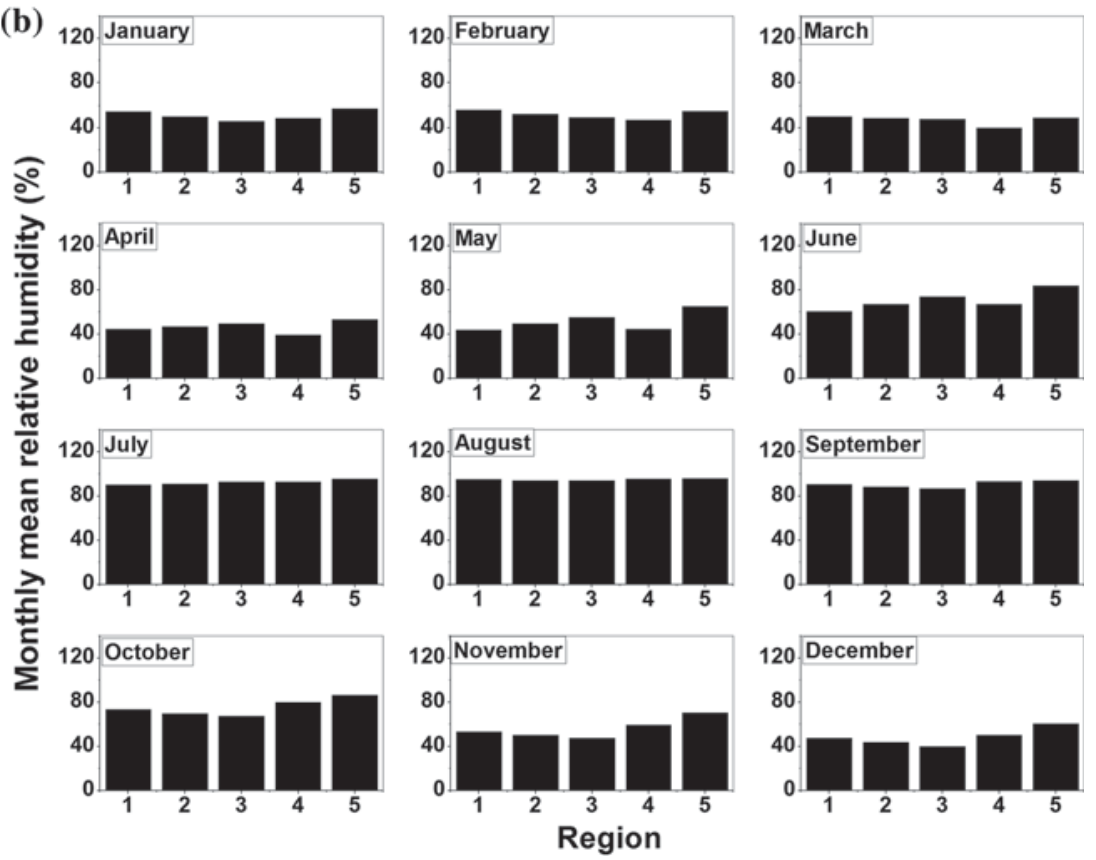

Figure 7. (a) Monthly mean variation of relative humidity over Nepal during 16 yr from 1998 to 2013 . (b) Monthly mean variation of relative humidity over the five regions of Nepal during 16 yr from 1998 to 2013.

over Nepal. For this purpose, we searched all the available Cloudsat data (2007-2013) which overlap with the swath time of the LIS data. But we did not find any Cloudsat swath during the intense thunderstorm period except a few intense thunderstorms. So, we performed one case study to show the relation between hydrometeors and lightning activity over Nepal and found a satisfactory result.

\section{Discussions}

In the present work, we investigated the lightning climatology in Nepal from 1998 to 2013. After analysing the LIS data over $16 \mathrm{yr}$, we find that the lightning flash rate density reaches the maximum in the month of May. We also found the same result for the year 2011 as observed from two ground-based networks WWLLN and GLN. But in the year 2012, WWLLN showed maximum activity in May, whereas GLN showed maximum activity only in the month of June. In the year 2013, GLN showed maximum detection in the month of April whereas WWLLN showed significant activity in the month of June. The months of April and May might be considered the most lightning-producing months in general over Nepal if we consider a long-term trend in lightning climatology. Most of the lightning activity 
(a)

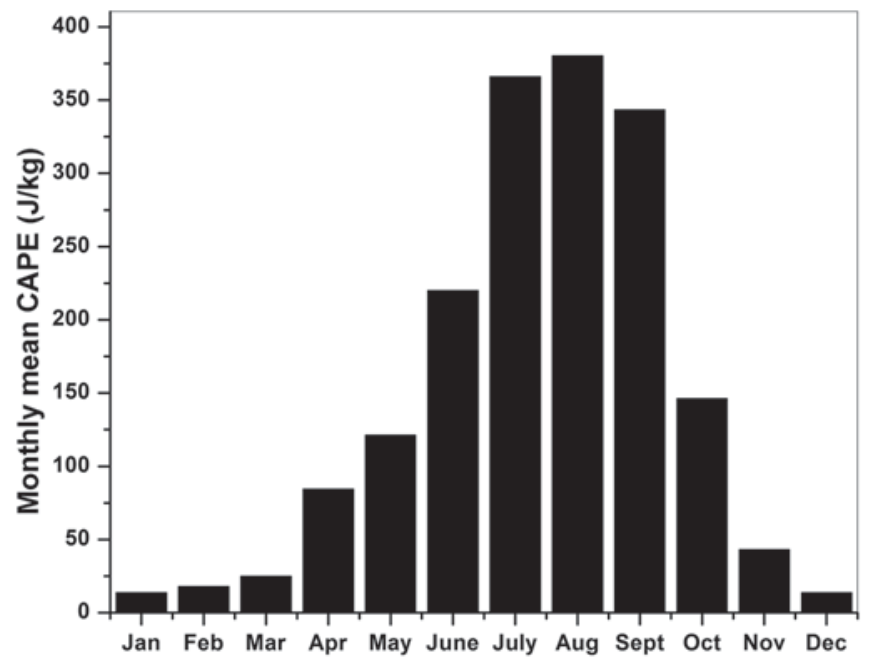

(b)
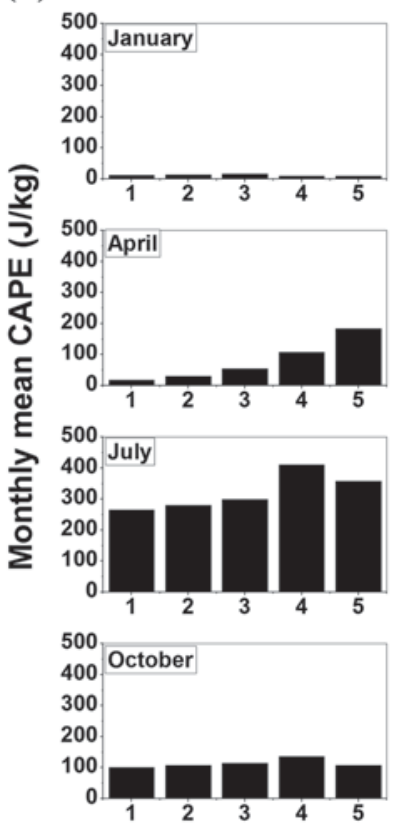

Month
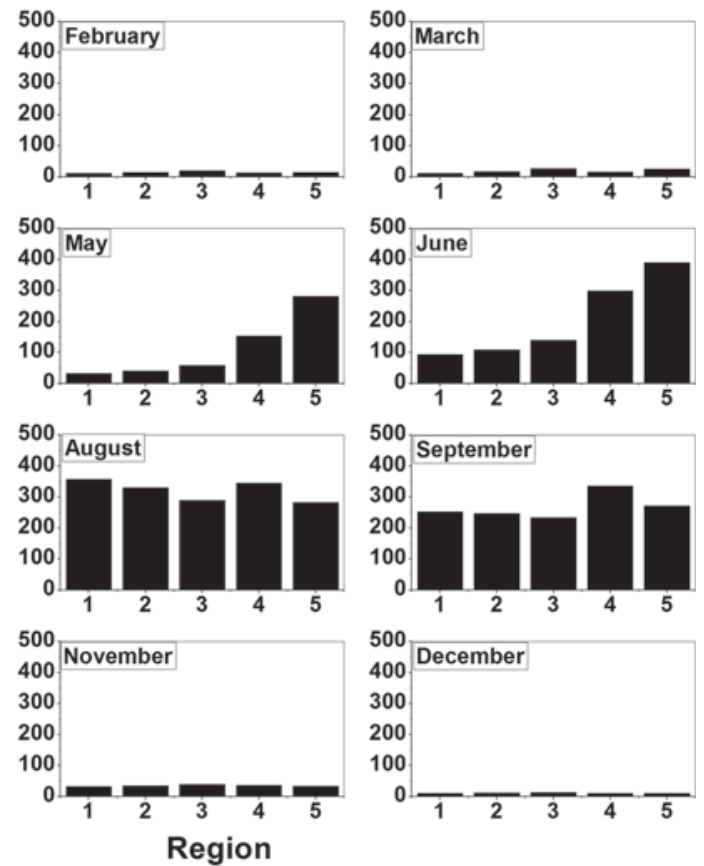

Figure 8. (a) Monthly mean variation of CAPE over Nepal during $16 \mathrm{yr}$ from 1998 to 2013. (b) Monthly mean variation of CAPE over the five regions of Nepal during 16 yr from 1998 to 2013.

originates from the central and eastern parts of the country.

The observed results are independently supported by the thunderstorm frequency analysis. As the detection efficiencies of the ground-based networks depend on several factors that include a number of receivers operating at a particular time of observation, we consider the observation from LIS to be the most reliable for climatological studies among the three lightning detection networks. This result is in contrast to the previously reported results (Makela et al. 2014) that utilised only 1 yr data from Vaisala Global Lightning
Dataset 360 (GLD360) to conclude that the maximum activity in lightning occurs in the month of June in Nepal.

The general observation of peak activity in the months of April and May is also consistent with the previous studies (Kumar and Kamra 2012) that show that the most severe and the tallest (cloud top reaching around $20 \mathrm{~km}$ in height) premonsoon cumulonimbus storms that occur due to the deep convection over the Ganges delta region (Weston 1972) which is similar to the severe storm outbreaks in the United States (Carlson et al. 1983; Bluestein 1993). Furthermore, 
(a)

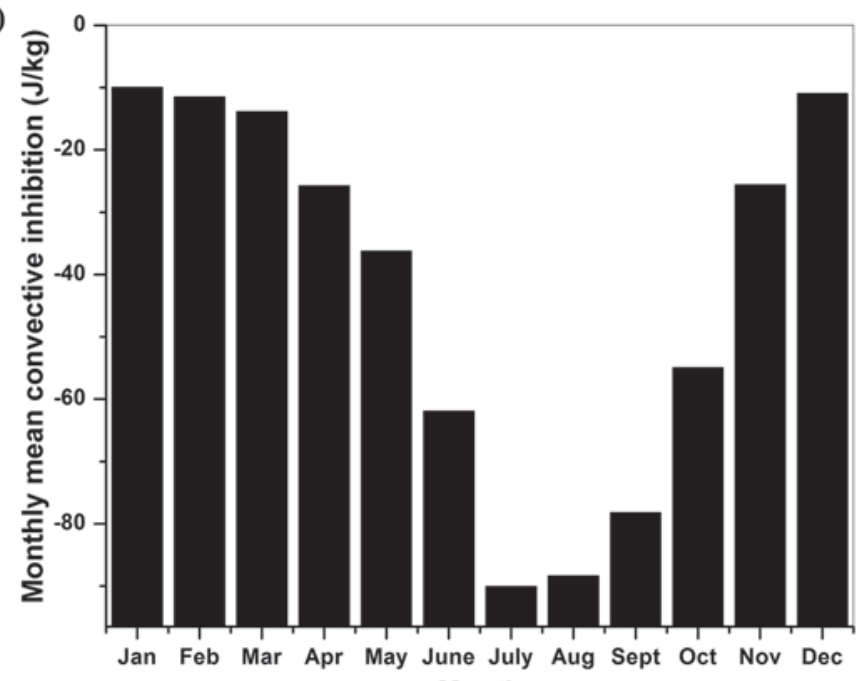

(b)

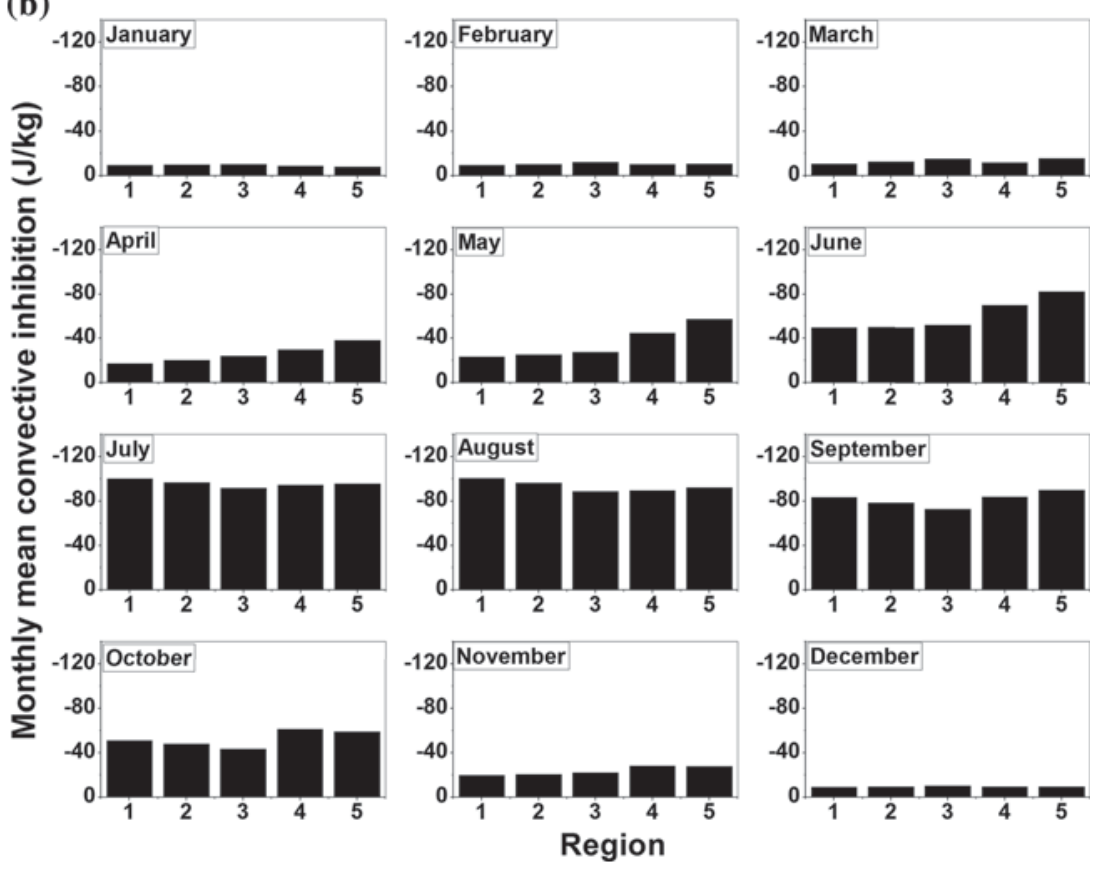

Figure 9. (a) Monthly mean variation of CIN over the Nepal during 16 yr from 1998 to 2013. (b) Monthly mean variation of CIN over the five regions of Nepal during 16 yr from 1998 to 2013.

Yamane and Hayashi (2006) found that the large static instability and vertical wind shear of this region favour severe thunderstorms and also the changing of the geographical distribution of the cumulonimbus cloud changes by the heat flux of the land surface, wide convective cores, regional variation of the surface temperature, atmospheric moisture, atmospheric inversions, vertical stability, topography of the region (Kumar and Kamra 2012) CAPE and aerosol loading which could affect the lightning occurrence on a regional scale (Baral and Mackerras 1992; Romatschke et al. 2010; Guha et al. 2016) in the pre-monsoon season.
It is to be noted that the lightning flash density of the south-eastern part (the green-coloured region of the middle to the eastern part of Nepal in figure 1) of Nepal is the maximum compared to other parts. This could be due to an elevated surface temperature in that region because the maximum part of the south-eastern region is covered under the Terai region. The Terai region is much warmer than the hilly and the mountainous region. As a result, atmospheric instability leads to orographic lifting of the air parcels and may also contribute to the formation of mesoscale convective complexes (MCCs) and DSCs (Kumar and Kamra 2012). Thus, this region may produce 

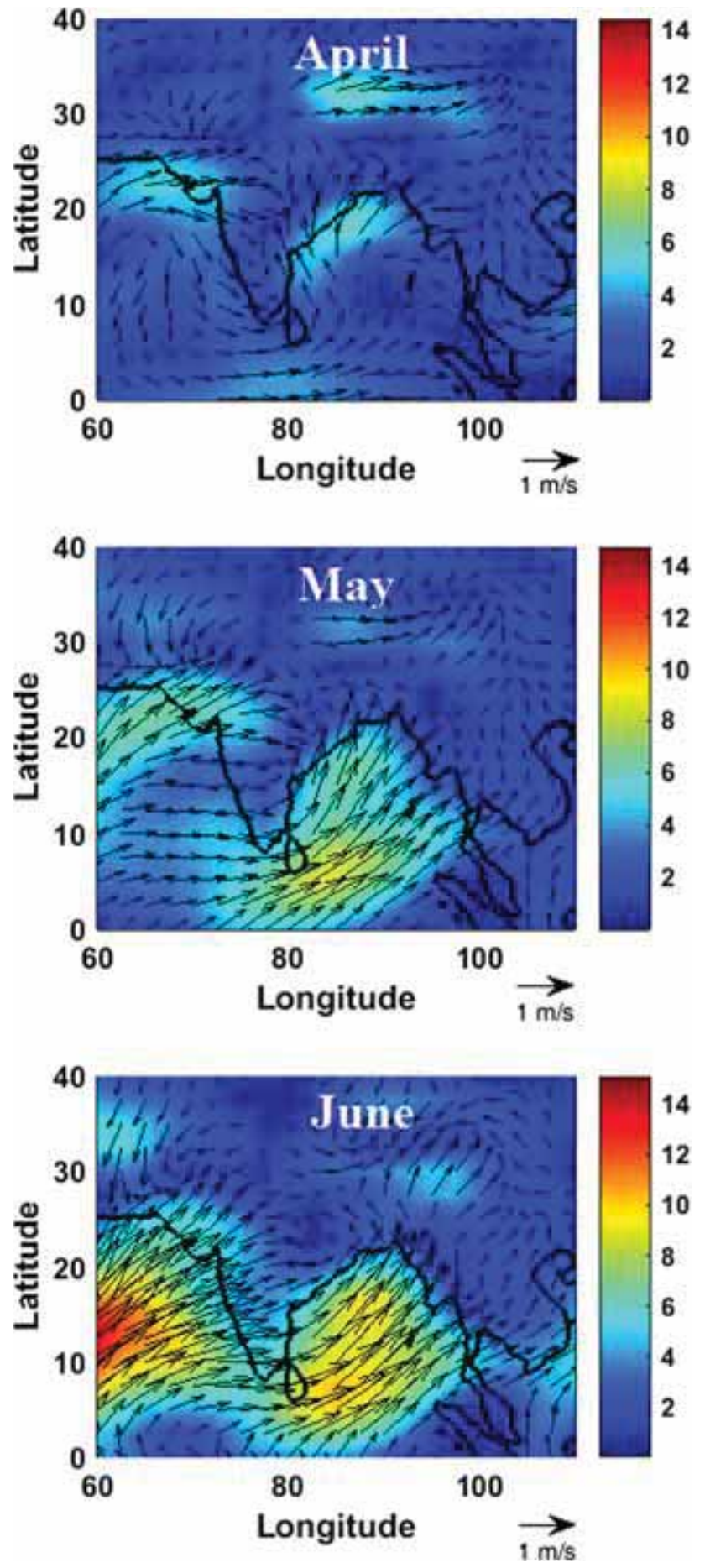

Figure 10. The upper, middle and lower panels represent the monthly mean wind flow direction at $1000 \mathrm{hPa}$ over the Indian subcontinent during the period of April to June for $16 \mathrm{yr}$ from 1998 to 2013 . The arrow sign represents the wind direction and the shaded contours indicate wind magnitude.

intense lightning activity. Also, the saturated air mass from the Bay of Bengal entering into the landmass encountering the steep hills and mountains leads to the high turbulence which may also be attributed towards producing a large number of

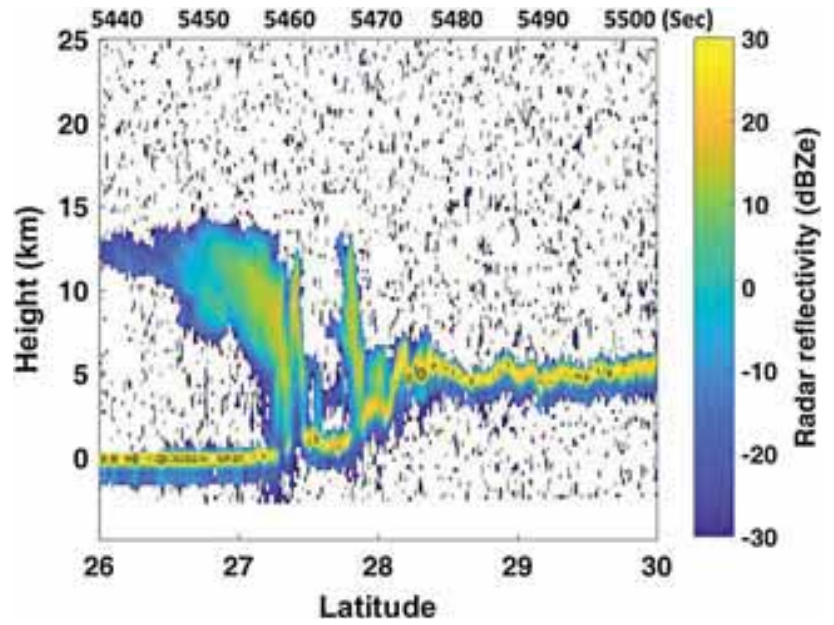

Figure 11. The radar reflectivity of the thunderstorm cloud over the Nepal region around 20 UT on 12 June 2007. This reflectivity represents the presence of hydrometeors when the Cloudsat satellite passes over the Nepal region. Latitude and swath time are represented along the bottom and the top of the $x$-axis, and along the left and right sides of the $y$-axis, the height and reflectivity.

lightning activities in the western to the eastern region.

\section{Concluding remarks}

The lightning activity studied from the LIS data over a period of $16 \mathrm{yr}$ has been analysed over Nepal. The maximum total lightning activity occurs during the month of April and May in the central and eastern regions and not during the month of June in the pre-monsoon period as reported by previous researchers. The surface temperature exerts a strong effect on the spatiotemporal variation of lightning over the region along with some other parameters such as atmospheric moisture, elevation and the topography of the region. The lightning flash rate over the region shows good correlation with the surface temperature and relative humidity. Our analysis also reveals that a ground-based lightning detection network might suffer from detection efficiency issues for a specific region that might be supplemented by satellite-based detection, especially for long-term observation. Although it is difficult to investigate the diurnal cycle of the lightning activity over a specific region from lower earth orbit satellites as the swath over the Earth's surface changes over time, for a monthly integration period, satellite-based observation could provide valuable information on the spatio-temporal variation of lightning over a specific region. 


\section{Acknowledgements}

We cordially thank Prof. Robert H Holzworth, University of Washington, USA for the provision of the WWLLN data, NASA GSFC for the LIS lightning data WSI for the provision of the GLN data. The authors are thankful to Disaster Information Management System (Desinventar) for giving access to the thunderstorm data over Nepal and also the National Center for Atmospheric Research for given NCEP/NCAR reanalysis vector wind data at a different pressure level along with surface temperature, relative humidity, CAPE and CIN. The authors also thank the NASA Earth System Science for providing us the valuable Cloudsat data. The work was supported by the NAM S\&T Centre by providing research training fellowship for developing country scientists (RTFDCS) - Award of Fellowship for 2016-2017 to the second author of this manuscript, the LDN project, funded by the Society for Applied Microwave Electronics Engineering \& Research (SAMEER), Ministry of Communications \& Information Technology, Government of India and DST-FIST fund reference Ref.SR/FST/PSI-191/2014, Government of India.

\section{References}

Agnihotri G and Dimri A P 2015 Vertical structure of atmosphere in pre-monsoon season over Bangalore; $J$. Earth Syst. Sci. 124 1563-1572.

Baral K N and Mackerras D 1992 The cloud flash-to-ground flash ratio and other lightning occurrence characteristics in Kathmandu thunderstorms; J. Geophys. Res. 97 931-938.

Barros A P and Lang T J 2003 Exploring spatial modes of variability of terrain-atmosphere interactions in the Himalayas during monsoon onset; Hydro Sciences Report Series, 03-001, Division of Engineering and Applied Sciences, Harvard University, 51p.

Barros A P, Joshi M, Putkonen J and Burbank D W 2000 A study of the 1999 monsoon rainfall in a mountainous region in central Nepal using TRMM products and rain gauge observations; Geophys. Res. Lett. 27 3683-3686.

Barros A P, Kim G, Williams E and Nesbitt S W 2004 Probing orographic controls in the Himalayas during the monsoon using satellite imagery; Nat. Hazards 4 29-51.

Boeck W L, Mach D, Goodman S J and Christian H J Jr 1999 Optical observations of lightning in Northern India, Himalayan mountain countries and Tibet; In: 11th International conference on atmospheric electricity, NASA Conf. Publication, NASA/CP-1999-209261, pp. 420-423.

Boccippio D J, Koshak W J and Blakeslee R J 2002 Performance assessment of the optical transient detector and lightning imaging sensor. Part I: Predicted diurnal variability; J. Atmos. Ocean. Technol. 19 1318-1332.
Bluestein H B 1993 Observations and theory of weather systems; vol. 2, Synoptic-dynamic meteorology in midlatitudes, Oxford University Press, 282p.

Carlson T, Benjamin S, Forbes G and Li Y F 1983 Elevated mixed layers in the regional severe storm environment; conceptual model and case studies; Mon. Weather Rev. 111 1453-1474.

Christian H J and Goodman S J 1987 Optical observations of lightning from a high altitude airplane; J. Atmos. Ocean. Technol. 4 701-711.

Christian H J et al. 1999 The lightning imaging sensor; In: NASA Conference Publication, NASA, pp. 746-749.

Christian H J, Blakeslee R J, Boccippio D J, Boeck W L, Buechler D E, Driscoll K T, Goodman S J, Hall J M, Koshak W J, Mach D M and Stewart M F 2003 Global frequency and distribution of lightning as observed from space by the optical transient detector; J. Geophys. Res. 108 ACL 4-1-ACL 4-15.

Cecil D J, Buechler D E and Blakeslee R J 2014 Gridded lightning climatology from TRMM-LIS and OTD: Dataset description; Atmos. Res. 135-136 404-414.

Das S K, Golhait R B and Uma K N 2017 Clouds vertical properties over the northern hemisphere monsoon regions from Cloudsat-CALIPSO measurements; Atmos. Res., http://dx.doi.org/10.1016/j.atmosres.2016.08.011.

Dowden R L, Brundell J B and Rodger C J 2002 VLF lightning location by time of group arrival (TOGA) at multiple sites; J. Atmos. Sol-Terr. Phys. 64(7) 817-830.

Fan J, et al. 2009 Dominant role by vertical wind shear in regulating aerosol effects on deep convective clouds; $J$. Geophys. Res. 114 D22206, http://dx.doi.org/10.1029/ 2009JD012352.

Goswami B B, Mukhopadhyay P, Mahanta R and Goswami B N 2010 Multiscale interaction with topography and extreme rainfall events in the North-East Indian region; J. Geophys. Res., https://doi.org/10.1029/2009jd012275.

Guha A, Banik T, De B K, Roy R and Choudhury A 2016 The effect of El Nino and La Nina on lightning activity: Its relation with meteorological and cloud microphysical parameters; Nat. Hazards 85 403-424.

He H, McGinnis J W, Song Z and Yanai M 1987 Onset of the Asian monsoon in 1979 and the effect of the Tibetan Plateau; Mon. Weather Rev. 115 1966-1995.

Hutchins M L, Holzworth R H, Virts K S, Wallace J M and Heckman S 2013 Radiated VLF energy differences of land and oceanic lightning; Geophys. Res. Lett. 40 2390-2394, https://doi.org/10.1002/grl.50406.

IPCC, Intergovernmental Panel on Climate Change 2007 The physical science basis; Cambridge University Press, New York, pp. 131-216.

Jayaratne E R and Kuleshov Y 2006 The relationship between lightning activity and surface wet bulb temperature and its variation with latitude in Australia; Meteorol. Atmos. Phys. 91 17-24. https://doi.org/10.1007/s00703-004-0100-0.

Kistler R E, et al. 2001 The NCEP-NCAR50-yr reanalysis: Monthly means CD-ROM and documentation; Bull. Am. Meteorol. Soc. 82 247-268.

Krishnamurti T N and Kishtawal C M 2000 A pronounced continental-scale diurnal mode of the Asian summer monsoon; Mon. Weather Rev. 128 462-473.

Kayastha S P and Regmi S K 2008 Nor'westers and tornadoes over the SAARC region and their forecasting and 
preparedness; In: Proceedings of the South Asian Association for Regional Cooperation (SAARC) Seminar, 20-21 August 2008, Dhaka, Bangladesh, pp. 28-34.

Khain A P 2009 Notes on state-of-the-art investigations of aerosol effects on precipitation: A critical review; Env. Res. Lett. 4 015004, http://dx.doi.org/10.1088/1748-9326/4/1/ 015004.

Kumar P R and Kamra A K 2012 The spatiotemporal variability of lightning activity in the Himalayan foothills; J. Geophys. Res. 117, https://doi.org/10.1029/2012jd018246.

Lang T J and Barros A P 2002 An investigation of the onset of the 1999 and 2000 monsoons in central Nepal; Mon. Weather. Rev. 130 1299-1316.

Lee S S, Donner L J, Phillips V T J and Ming Y 2008 The dependence of aerosol effects on clouds and precipitation on cloud-system organization, shear and stability; J. Geophys. Res. 113 D16202. http://dx.doi.org/10.1029/2007JD009224.

Lee S S, Donner L J and Penner J E 2010 Thunderstorm and stratocumulus: How does their contrasting morphology affect their interactions with aerosols? Atmos. Chem. Phys. 10 6819-6837, http://dx.doi.org/10.5194/acp-10-6819-2010.

MacGorman D R and Rust W D 1998 The electrical nature of storms; Oxford Univ. Press, New York, NY.

Mace G G, Marchand R, Zhang Q and Stephens G 2007 Global hydrometeor occurrence as observed by CloudSat: Initial observations from summer 2006; Geophys. Res. Lett. 34 L09808, http://dx.doi.org/10.1029/2006GL029017.

Makela A, Sherstha R and Karki R 2014 Thunderstorm characteristics in Nepal during the pre-monsoon season 2012; Atmos. Res. 137 91-99.

Malla G 2008 Climate change and its impact on Nepalese agriculture; J. Agric. Env. 9.

Mansell E R, MacGorman D R, Ziegler C L, Straka J M 2005 Charge structure and lightning sensitivity in a simulated multicell thunderstorm; J. Geophys. Res. 110, https://doi. org/10.1029/2004JD005287.

Pawar V, Pawar S D, Beig G and Sahu S K 2012 Effect of lightning activity on surface $\mathrm{NOx}$ and $\mathrm{O} 3$ over a tropical station during pre-monsoon and monsoon seasons; $J$. Geophys. Res. 117 D05310, http://dx.doi.org/10.1029/ 2011JD016930.

Pawar S D, Gopalakrishnan V and Murugavel P 2015 Role of orography in inducing high lightning flash rate at the foothills of Himalaya; Earth Planets Space 67 51, https:// doi.org/10.1186/s40623-015-0221-3.

Pessi A T and Businger S 2009 The impact of lightning data assimilation on a winter storm simulation over the North Pacific Ocean; Am. Meteorol. Soc., https://doi.org/10. 1175/2009mwr2765.1.

Price C and Asfur M 2005 Can lightning observations be used as an indicator of upper-tropospheric water vapor variability?
Bull. Am. Meterol. Soc. 87(3) 291-298, https://doi.org/10. 1175/bams-87-3-29i.

Rakov V A and Uman M A 2003 Lightning: Physics and E_ects; Cambridge Univ. Press, Cambridge, UK, New York.

Robinson P J and Henderson-Sellers A 1999 Contemporary characteristics; Addison Wesley, Longman, 317p.

Romatschke U, Medina S and Houze R A Jr 2010 Regional, seasonal, and diurnal variations of extreme convection in the South Asian region; J. Clim. 23 419-439.

Rudlosky SD and Shea DT 2013 Evaluating WWLLN performance relative to TRMM/LIS; Geophys. Res. Lett. 40 1-5, https://doi.org/10.1002/grl.50428.

Sarkar S K, Bhattacharya A B and Sen A K 1980 Characteristics of VLF atmospherics during tropical thunderstorm; Arch. Meteorol. Geophys. A 29 131-141.

Saunders C P R 1993 A review of thunderstorm electrification processes; J. Appl. Meteorol. 32(4) 642-655.

Shrestha M L 2000 Interannual variation of summer monsoon rainfall over Nepal and its relation to the Southern Oscillation Index; Meteorol. Atmos. Phys. 75 21-28.

Stolzenburg M, Rust W D and Marshall T C 1998 Electrical structure in thunderstorm convective regions 1 . Mesoscale convective systems; J. Geophys. Res. 103(D12) 14059-14078, https://doi.org/10.1029/97jd03546.

Siingh D, Buchunde P S, Singh R P, Nath A, Kumar S and Ghodpage R N 2014 Lightning and convective rain study in different parts of India; J. Atmos. Res. 137 35-48.

Soula S, Kigosti Kasereka J, Georgis J F and Barthe C 2016 Lightning climatology in the Congo basin; Atmos Res. 178-179 304-319.

Srivastava S, Ray P K C, Shakya B, Joshi D, Kumar D R and Dhar P G 2007 South Asian Disaster Report (SAARC Disaster Management Center, New Delhi).

Wang S S, Zheng J Y, et al. 2011 Development of an emission processing system for the Pearl River Delta Regional air quality modeling using the SMOKE model: Methodology and evaluation; Atmos. Env. 45(29) 5079-5089.

Weston K J 1972 The dry-line of northern India and its role in cumulonimbus convection; Quart. J. Roy. Meteorol. Soc. 98 519-532.

Williams E R 2005 Lightning and climate: A review; Atmos. Res. 76 272-287, http://dx.doi.org/10.1016/j.atmosres. 2004.11.014.

Winn W P, Schwede G W and Moore C B 1974 Measurements of electric fields in thunderclouds; J. Geophys. Res. $\mathbf{7 9}(\mathbf{1 2})$ 176.

Yamane Y and Hayashi T 2006 Evaluation of environmental conditions for the formation of severe local storms across the Indian subcontinent; Geophys. Res. Lett. 33 L17806, https://doi.org/10.1029/2006gl026823 